\title{
An Improved Absorption Ångström Exponent (AAE)-Based Method for Evaluating the Contribution of Light Absorption from Brown Carbon with a High-Time Resolution
}

\author{
Guohua Zhang ${ }^{1 *}$, Long Peng ${ }^{1,2}$, Xiufeng Lian ${ }^{1,2}$, Qinhao Lin ${ }^{1}$, Xinhui Bi ${ }^{1}$, Duohong Chen ${ }^{3}$, \\ Mei Li ${ }^{4}$, Lei Li ${ }^{4}$, Xinming Wang ${ }^{1}$, Guoying Sheng ${ }^{1}$ \\ ${ }^{I}$ State Key Laboratory of Organic Geochemistry and Guangdong Key Laboratory of Environmental Resources Utilization \\ and Protection, Guangzhou Institute of Geochemistry, Chinese Academy of Sciences, Guangzhou 510640, China \\ ${ }^{2}$ University of Chinese Academy of Sciences, Beijing 100039, China \\ ${ }^{3}$ State Environmental Protection Key Laboratory of Regional Air Quality Monitoring, Guangdong Environmental \\ Monitoring Center, Guangzhou 510308, China \\ ${ }^{4}$ Institute of Mass Spectrometer and Atmospheric Environment, Jinan University, Guangzhou 510632, China
}

\begin{abstract}
While brown carbon $(\mathrm{BrC})$ might play a substantially important role in radiative forcing, an estimation of its light absorption contribution with high-time resolution is still challenging. In this study, a multi-wavelength (370-950 nm) Aethalometer was applied to obtain the wavelength dependent light absorption coefficient $\left(\sigma_{\mathrm{abs}}\right)$ of aerosols both before and after being heated to $250^{\circ} \mathrm{C}$. An improved absorption Ångström exponent (AAE)-based method was developed to evaluate the contribution of $\mathrm{BrC}$ to light absorption at a wavelength of $370 \mathrm{~nm}\left(\sigma_{\mathrm{abs}, \mathrm{BrC}} / \sigma_{\mathrm{abs}, 370 \mathrm{~nm}}\right)$. The $\sigma_{\mathrm{abs}, \mathrm{BC}}$ at $370 \mathrm{~nm}$ was determined from the field measured AAE values for the wavelengths from 880 to $950 \mathrm{~nm}$ with a one-hour resolution. The simultaneous measurements of heated aerosols help confirm the negligible influence of $\mathrm{BrC}$ on the $\sigma_{\mathrm{abs}}$ values across the range of $880-950 \mathrm{~nm}$. Meanwhile, $\sigma_{\mathrm{abs}, \mathrm{Br} C} / \sigma_{\mathrm{abs}, 370 \mathrm{~nm}}$ was also estimated with previously reported methods by assuming that the AAE was equal to 1 (Method I) as well as a new approach based on the light absorption enhancement (Method II). While the estimated $\sigma_{a b s, B r C} / \sigma_{a b s, 370 \mathrm{~nm}}$ based on our developed method and Method I is highly correlated $\left(\mathrm{r}^{2}=0.78\right)$, the difference could be as large as $>20 \%$ on average. The obtained mean $\sigma_{\text {abs,BrC }} / \sigma_{\text {abs,370nm }}$ was negative with Method II, indicating the net production of $\mathrm{BrC}$ when the aerosols were heated. The difference between the values for $\sigma_{\mathrm{abs}, \mathrm{BrC}} / \sigma_{\mathrm{abs}, 370 \mathrm{~nm}}$ obtained by our developed method and by Method II was $\sim 40 \%$ on average and much higher $(>50 \%)$ during the noon hour, when secondary organic aerosols and sulfate were abundant. We propose that it is more suitable to use an AAE around 0.7 for "pure" $\mathrm{BC}$ to evaluate the contribution of $\mathrm{BrC}$ to light absorption in the PRD region. The developed method thus helps improve our understanding of the light absorption and climate forcing of $\mathrm{BrC}$.
\end{abstract}

Keywords: Brown carbon; Black carbon; Light absorption; Absorption Ångström exponent; Aethalometer; PRD region.

\section{INTRODUCTION}

Most climate models regard black carbon $(\mathrm{BC})$ as the sole light-absorbing particulate material. However, some organic species (i.e., brown carbon/BrC) could also absorb solar radiation, and thus play an important role in radiative forcing (Liu et al., 2014; Liu et al., 2015; Shamjad et al., 2015). Recently, high contribution of $\mathrm{BrC}$ to light absorption is reported worldwide from satellite and ground observations, and modeling studies (Bahadur et al., 2012; Feng et al., 2013;

\footnotetext{
${ }^{*}$ Corresponding author.

E-mail address: zhanggh@gig.ac.cn
}

Laskin et al., 2015, and references therein). Overwhelming presence of $\mathrm{BrC}$ above the Yellow Sea shows the necessity for understanding more than just bulk $\mathrm{BC}$ and organic carbon fractions of Asian aerosols (Alexander et al., 2008; Zhu et al., 2013). However, the variable absorptivity of light-absorbing carbonaceous aerosols is poorly known, making it challenging to account for their roles in radiative forcing (Andreae and Gelencser, 2006; Laskin et al., 2015). Therefore, an accurate estimation of $\mathrm{BrC}$ light absorption is essential both for constraining large uncertainties in current aerosol forcing estimates and for control policy development (Bergstrom et al., 2007; Zhang et al., 2013b; Saleh et al., 2014).

The $\mathrm{BrC}$ light absorption is strongly dependent on the wavelength (Favez et al., 2009; Moosmüller et al., 2011), 
parameterized by absorption Ångström exponent (AAE). AAE has commonly been used to estimate the contribution of $\mathrm{BrC}$ to light absorption (Corr et al., 2012; Kirchstetter and Thatcher, 2012). Previous studies indicate that the AAE of "pure" BC is around 1 in the climate relevant wavelength region of the solar spectrum, and the presence of $\mathrm{BrC}$ will increase the AAE due to its enhanced absorption at UV/near-UV wavelengths (Kirchstetter et al., 2004; Yang et al., 2009; Rathod et al., 2017). So, the measured wavelength dependence of AAE can be used to provide a quantitative estimate of $\mathrm{BrC}$ (Sandradewi et al., 2008; Harrison et al., 2012), and also for further distinction of sources (Ajtai et al., 2011; Pintér et al., 2018). However, theoretical calculations and field studies have shown that the likely range of AAE for internally mixed $\mathrm{BC}$ varies in a range of approximate 1-1.7, depending on the size and optical properties of the particle core and non-absorbing coating and the wavelength pairs used to determine AAE (Gyawali et al., 2009; Lack and Cappa, 2010; Lin et al., 2016). Using a three wavelength photo-acoustic soot spectrometer (PASS-3) and aerosol mass spectrometers (AMS), Yuan et al. (2016) explored the relationship between the measured AAE and the relative abundance of organic aerosol to $\mathrm{BC}$ and derived more realistic $\mathrm{AAE}$ values for "pure" BC aerosol, which is significantly lower than 1. Contributions to total light absorption at $370 \mathrm{~nm}$ by $\mathrm{BrC}$ were also estimated by comparing the wavelength dependence of the absorption coefficients of aerosols before and after heating (Guo et al., 2014). This is based on the assumption that the change of AAE for aerosols after heating is due to the evaporation of $\mathrm{BrC}$, but the potential error of which has not been fully assessed.

In the present work, the optical, physical, and chemical properties of atmospheric aerosols were measured before and after heating in the Pearl River Delta (PRD) region, China. In this region, organics are the second largest contributor for light extinction (Zhang et al., 2013a; Chen et al., 2016), and the average light absorption contributions of $\mathrm{BrC}$ at $405 \mathrm{~nm}$ were quantified to be $\sim 10 \%$. This work presents spectral measurements of light absorption coefficient $\left(\sigma_{\mathrm{abs}}\right)$ in a broad spectral range (370-950 nm) by an Aethalometer, highlighting some characteristics of light-absorbing aerosols. An improved method was developed, based on wavelength segregated AAE, in order to estimate the contribution of $\mathrm{BrC}$ to light absorption at $370 \mathrm{~nm}\left(\sigma_{\mathrm{abs}, \mathrm{Br}} / \sigma_{\mathrm{abs}, 370 \mathrm{~nm}}\right)$. Meanwhile, the $\mathrm{BrC}$ contribution was also compared to those estimated based on the previously reported methods.

\section{METHODS}

\section{Ambient Observation}

Ambient measurements were performed at Guangdong Atmospheric Supersite (22.73N, 112.93E), a suburban site (Zhang et al., 2014) in the PRD region from July 8 to August 2, 2014. Over the sampling period, ambient temperature and relative humidity generally varied between $24-37^{\circ} \mathrm{C}$ and $40-93 \%$, with an average of $29^{\circ} \mathrm{C}$ and $73 \%$, respectively. The concentration of $\mathrm{PM}_{2.5}$ varied in a wide range of $0.78-166 \mu \mathrm{g} \mathrm{m}^{-3}$, with mean value of $29.7 \mu \mathrm{g} \mathrm{m}^{-3}$.
Wind speed ranged between $0.3-5.1 \mathrm{~m} \mathrm{~s}^{-1}$ and the prevailing direction was from the southwest. Wind speed was lower $\left(\sim 1 \mathrm{~m} \mathrm{~s}^{-1}\right)$ during the early morning hours and was relatively higher $\left(\sim 2 \mathrm{~m} \mathrm{~s}^{-1}\right)$ in the afternoon.

To compare the properties of aerosols before and after heating, an automatic-controlled actuated ball valve that switches between "bypass" and "heating" on a 5-min cycle was used. The thermodenuder (TD, Dekati Ltd.) consists of a $95-\mathrm{cm}$ long stainless steel tube, where the particles can be heated with controlled temperature, i.e., $250^{\circ} \mathrm{C}$. The residence time of particles in the TD section is estimated to be $1.2 \mathrm{~s}$, which should be enough for the effective vaporization of semi-volatile species (Villani et al., 2007). Volatile or semi-volatile species, such as most organic compounds and ammonium nitrate, are supposed to evaporate during the heating ( $\mathrm{Bi}$ et al., 2015). Subsequently, these species were adsorbed in active charcoal in the adsorber section. The bypass consists of a silica tube of similar length for heating condition. In order to eliminate the influence of resident aerosols in the tubes, only the measurements during the latter 3-min of the 5-min cycle were included in the following data analysis. Particle loss could be typically represented as a function of flow rate and particle size (Stevanovic et al., 2015). The test made by the manufacturer shows that particles with a physical diameter $d_{\mathrm{p}} \leq 70 \mathrm{~nm}$ have a size dependent particle loss, increasing from $\sim 20 \%$ to $\sim 40 \%$ when $d_{\mathrm{p}}$ decreases from $70 \mathrm{~nm}$ to $10 \mathrm{~nm}$; particle loss at $d_{\mathrm{p}}>70 \mathrm{~nm}$ is estimated to be approximately $20 \%$ at the total flow rate of $10 \mathrm{~L} \mathrm{~min}^{-1}$, mainly attributed to the diffusion of particles. Regarding that the $d_{\mathrm{p}}$ of refractory $\mathrm{BC}$ was reported to be around $200 \mathrm{~nm}$ in the PRD region (Huang et al., 2011), the particle loss might lead to a $20 \%$ negative bias for $\sigma_{a b s}$ measured through the heated line. The BC around $200 \mathrm{~nm}$ was most probably attributed to be from traffic emission, with their diurnal variation similar to that of $\mathrm{NO}_{\mathrm{x}}$ (Qin et al., 2017), as shown in Fig. S1.

The $\sigma_{a b s}$ was determined in 1-min resolution by an Aethalometer (AE-33, Magee Scientific) with seven wavelengths (at 370, 470, 520, 590, 660, 880 and $950 \mathrm{~nm}$, respectively). A single particle aerosol mass spectrometer (SPAMS, Hexin Analytical Instrument Co., Ltd.) was deployed to measure the size and mass spectra of individual particles (Li et al., 2011). Aethalometer and SPAMS shared an aerosol inlet (dried total suspended aerosols) and were placed downstream of the TD. Additionally, the concentrations of water soluble ions associated with $\mathrm{PM}_{2.5}$ were obtained from a Monitor for AeRosols and GAses in ambient air (MARGA) (Rumsey et al., 2014). Hourly variations of organic carbon (OC)/elemental carbon (EC) in $\mathrm{PM}_{2.5}$ were provided by a Sunset Semi-Continuous Aerosol Analyzer. Concentration of $\mathrm{O}_{3}$ was measured using an ozone analyzer (Model 49i, Thermo-Fisher Scientific). For comparison, all the measured parameters are presented as hourly averages in this paper. A detailed description of the instruments and the data analysis can be found in Supporting Information (SI).

\section{Light Absorption Measurements}

Generally, filter-based optical measurement instruments 
(e.g., Aethalometer) must take into account the "filter loading effect" to accurately determine the $\sigma_{\mathrm{abs}}$ (Arnott $e t$ al., 2005; Ajtai et al., 2011). The new version Aethalometer (AE-33) used in the present study has been improved with the filter loading correction part, based on a two parallel spot measurement of optical absorption, through providing a real-time output of the "loading compensation" parameter to compensate for the "loading effect," in detail described in the SI. The details of operation principle, data deduction, error budget of AE-33, inherent uncertainties in its technique and the corrections are extensively available in the literature (Drinovec et al., 2015). The BC mass concentration is calculated from the change in optical attenuation at $880 \mathrm{~nm}$ in the selected time interval using the mass absorption cross section (MAC) of $7.77 \mathrm{~m}^{2} \mathrm{~g}^{-1}$, which is close to that reported in the PRD region (Cheng et al., 2011). The noise level of AE-33 at the time-base of 1 minute is $<0.016 \mathrm{Mm}^{-1}$ for the $\sigma_{\mathrm{abs}}$ (http://www.mag escientific.com/). The contribution of dust to $\sigma_{a b s}$ can be considered to be negligible in the PRD region (Yuan et al., 2016), due to limited mass fraction (Cheng et al., 2008; Zhang et al., 2013a), and lower mass absorption efficiency values (Favez et al., 2009).

\section{RESULTS AND DISCUSSION}

\section{Previous Methods to Estimate the Light Absorption from} $\mathrm{BrC}$

Method I: Assuming $A A E=1$ for "Pure" $B C$

The wavelength $(\lambda)$ dependence of $\sigma_{a b s}$ is usually approximated by a power-law expression (e.g., Bergstrom et al., 2007), defined as:

$\sigma_{\mathrm{abs}}=K \times \lambda^{-\mathrm{AAE}}$

where $K$ is a constant. In practice for multi-wavelength measurements, AAE can be retrieved by fitting the $\sigma_{a b s}$ to the $\lambda(370-950 \mathrm{~nm})$, or to the different wavelength ranges (Bergstrom et al., 2007). Thus, a wavelength segregated AAE value can be obtained through the logarithmic fit of $\mathrm{R} 1$, or $\mathrm{AAE}=\ln \left(\sigma_{\mathrm{abs} 1} / \sigma_{\mathrm{abs} 2}\right) / \ln \left(\lambda_{1} / \lambda_{2}\right)$ for two wavelengths.

The AAE has often been used as a simplified method for attributing short visible wavelength absorption to $\mathrm{BrC}$ (Lack and Cappa, 2010). Light absorption at longer wavelength $(950 \mathrm{~nm})$ is assumed to be due only to $\mathrm{BC}$, and is extrapolated to the shorter wavelength using an assumed AAE, most commonly 1, which is illustrated in Fig. 1. It estimates the $\sigma_{\mathrm{abs}, \mathrm{BrC}}$ at $370 \mathrm{~nm}$ by subtracting the measured $\sigma_{\mathrm{abs}}$ to the extrapolated $\sigma_{\mathrm{abs}, \mathrm{BC}}$ at $370 \mathrm{~nm}$ ("Method I"):

$\sigma_{\mathrm{abs}, \mathrm{BrC}}=\sigma_{\mathrm{abs}, 370 \mathrm{~nm}}-\sigma_{\mathrm{abs}, 950 \mathrm{~nm}} \times(370 / 950)^{-\mathrm{AAE}}$

\section{Method II: Based on Light Absorption Enhancement}

The $\sigma_{\text {abs,BrC }} / \sigma_{\text {abs,370nm }}$ was also estimated based on the enhancements of $\sigma_{\mathrm{abs}}\left(E_{\mathrm{abs}}\right)$, defined as the ratio of $\sigma_{\mathrm{abs}}$ for ambient and heated aerosols $\left(E_{\mathrm{abs}}=\sigma_{\mathrm{abs}, \text { ambient }} / \sigma_{\mathrm{abs}, \mathrm{TD}}\right)$, at both 370 and $950 \mathrm{~nm}$ in previous studies (Cappa et al., 2012; Guo et al., 2014).

$\sigma_{\mathrm{abs}, \mathrm{BrC}} / \sigma_{\mathrm{abs}, 370 \mathrm{~nm}}=\left(E_{\mathrm{abs}, 370 \mathrm{~nm}}-E_{\mathrm{abs}, 950 \mathrm{~nm}}\right) / E_{\mathrm{abs}, 370 \mathrm{~nm}}$

where $\sigma_{\mathrm{abs}, \mathrm{BrC}}$ refers to the effective absorption coefficient

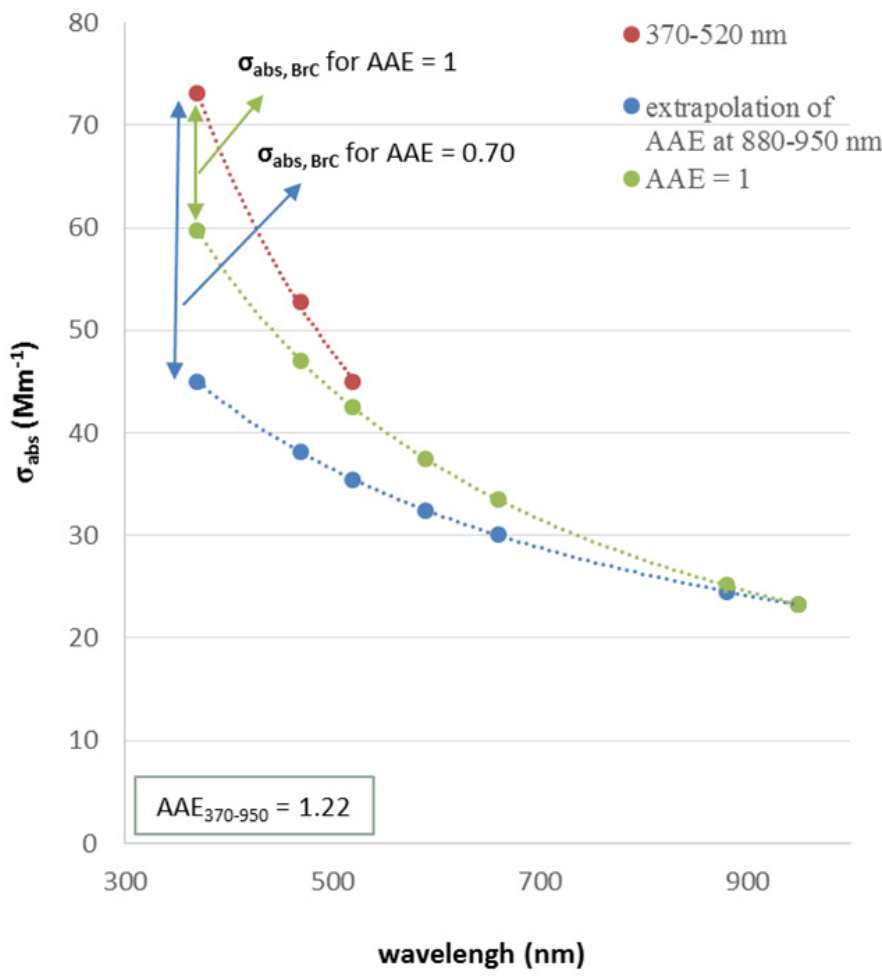

Fig. 1. An illustration of the methods to estimate the contribution of light absorption from BrC, based on the assumption of $\mathrm{AAE}=1$ for Method $\mathrm{I}$, and $\mathrm{AAE}=\mathrm{AAE}_{880-950}$ for our developed method. 
at $370 \mathrm{~nm}$ for the $\mathrm{BrC}$ evaporating under the $\mathrm{TD}$ temperature (i.e., $250^{\circ} \mathrm{C}$ ), which is slightly different from the definition in $\mathrm{R} 2$. When there is no evaporative $\mathrm{BrC}, E_{\text {abs,950nm }}$ should equal $E_{\mathrm{abs}, 370 \mathrm{~nm}}$, since evaporation of $\mathrm{BrC}$ would result in larger $E_{\mathrm{abs}, 370 \mathrm{~nm}}$ than $E_{\mathrm{abs}, 950 \mathrm{~nm}}$ (Cappa et al., 2012). It is worthy to note that this estimation (R3) actually represents the net result of evaporation and production of $\mathrm{BrC}$ in measured aerosol fraction.

\section{An improved AAE-Based Method Developed by this Study}

As far as the wavelength segregated AAE is concerned (Sandradewi et al., 2008; Mogo et al., 2012; Utry et al., 2014), the AAE determined over the wavelength of 370 $520 \mathrm{~nm}$ and $880-950 \mathrm{~nm}$ and their diurnal variations were compared in Fig. 2. $\mathrm{AAE}_{370-520}$ were $1.36 \pm 0.25$ and 1.41 \pm 0.22 , and $\mathrm{AAE}_{880-950}$ were $0.70 \pm 0.07$ and $0.68 \pm 0.08$ for ambient and heated particles, respectively. $\mathrm{AAE}_{880-950}$ were quite similar, indicating there was a thin coating and negligible lensing effect, which could be supported by the chemical composition of the ambient and heated BCcontaining particles detected by the SPAMS (Fig. S2). It can be seen that $\mathrm{AAE}_{880-950}$ varied in a narrow range $(0.63-0.78$, $10^{\text {th }}-90^{\text {th }}$ of the observed data), and significant difference $(p<0.001)$ was found between $\mathrm{AAE}_{370-520}$ and $\mathrm{AAE}_{880-950}$ for both ambient and heated particles, respectively. It reflects that $\sigma_{\mathrm{abs}}$ becomes more sensitive to spectral variations at lower wavelengths than at higher wavelengths, which is attributed to the presence of $\mathrm{BrC}$ (Mogo et al., 2012). While AAE is sensitive to these microphysical properties (Moosmüller et al., 2009; Lack and Cappa, 2010), the influence of particle size on the AAE for heated aerosols should be limited in the present study, since the difference of hourly average $\mathrm{AAE}_{880-950}$ for aerosols before and after heating was in a small range $(2 \% \pm 2 \%)$. Furthermore, there is no significant correlation $(p>0.05)$ between $\mathrm{AAE}_{880-950}$ and the mass fraction ratio of available coating materials $\left(\mathrm{PM}_{2.5}-\mathrm{BC}\right)$ to $\mathrm{BC}$, which further indicates limited influence of coating materials on the $\mathrm{AAE}_{880-950}$. In contrast, the difference between $\mathrm{AAE}_{370-520}$ for aerosols before and after heating was relatively higher $(-5 \% \pm 11 \%)$, which is more evidently shown in their diurnal variation (Fig. 2(b)). Correlation coefficients $\left(\mathrm{r}^{2}\right)$ between $\mathrm{AAE}_{370-520}$ and $\mathrm{AAE}_{590-950}, \mathrm{AAE}_{660-950}$, and $\mathrm{AAE}_{880-950}$ are $0.56,0.48$ and 0.17 , respectively, implying limited influence of $\mathrm{BrC}$ on the $\mathrm{AAE}_{880-950}$. Overall, these results supported that $\mathrm{AAE}_{880-950}$ may well represent the $\mathrm{AAE}$ of $\mathrm{BC}$ dominant aerosols in the present study. "Pure" BC AAE (i.e., $\mathrm{AAE}_{880-950}$ ) of $0.70 \pm 0.07$ inferred in this study is significantly lower than the widely adopted value $(\mathrm{AAE}=$ 1) (Bond and Bergstrom, 2006). While it might not be typical to have AAE of the "pure" BC lower than 1, the
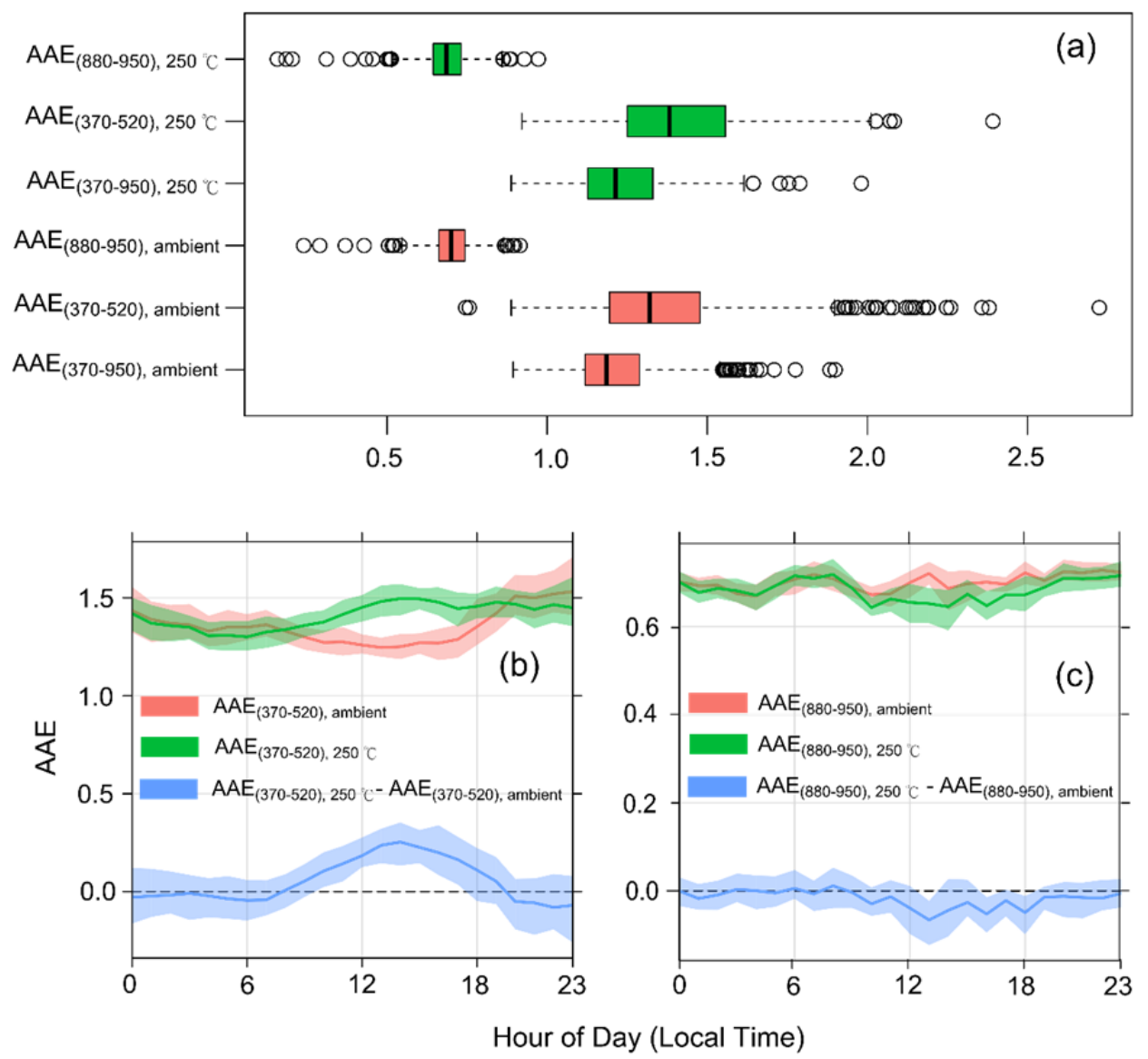

Fig. 2. (a) Comparison of AAE at the wavelength of 370-520, 880-950, and 370-950 nm, and diurnal variations of AAE at the wavelength of (b) 370-520 nm and, (c) 880-950 nm, for aerosols before and after heated, respectively. 
retrieved value in this study is quite similar to that (AAE between the wavelength at 532 and $781 \mathrm{~nm}$ ) estimated for the "pure" BC dominated from traffic emission in the same region (Yuan et al., 2016). Additionally, lower AAE values $(<1)$ have also been reported for the "pure" BC in traffic and biomass burning emissions (Kirchstetter et al., 2004), and at urban site in Beijing (Wu et al., 2015). Theoretical calculation shows that AAE decreases with the increasing of "pure" BC sizes (Wu et al., 2015). Regarding the reported volume equivalent diameter peak of "pure" $\mathrm{BC}$ to be around $200 \mathrm{~nm}$ in this region (Huang et al., 2011), the corresponding theoretical AAE would most probably vary between 0.4 and 1 (Wu et al., 2015). In addition, the fractal like structure of combustion generated $\mathrm{BC}$ could also be one possible explanation of the smaller value of AAE measured in this study (Moosmüller et al., 2009; Lack and Cappa, 2010). Therefore, based on the assumption that BC is the dominant absorbing species over the near-IR wavelength (Shrestha et al., 2014), it is proposed to apply $\mathrm{AAE}=\mathrm{AAE}_{880-950}$, instead of $\mathrm{AAE}=1$, in $\mathrm{R} 2$ to estimate $\sigma_{\mathrm{abs}, \mathrm{BrC}}$. Additionally, the input of hourly variation of $\mathrm{AAE}_{880-950}$ further accounts for the factors (e.g., sources and atmospheric processing) that have influence on $\mathrm{AAE}_{880-950}$ of BC dominant aerosols.

The uncertainty associated with this method was estimated through a sensitivity test. The upper and lower bound of hourly average $\sigma_{\mathrm{abs}}\left(\sigma_{\mathrm{abs}} \pm \operatorname{std}\left(\sigma_{\mathrm{abs}}\right)\right.$, std $\left(\sigma_{\mathrm{abs}}\right)$ refers to the standard deviation of $\sigma_{a b s}$ ) were inputted in R1 and R2 to obtain an estimate of the upper and lower bound of $\sigma_{\text {abs,BrC. }}$ Std $\left(\sigma_{a b s}\right)$ at 1-min time base is assumed to be three times the noise level $\left(0.016 \mathrm{Mm}^{-1}\right)$ of AE33, and thus hourly based std $\left(\sigma_{\mathrm{abs}}\right)$, averaged over 18-min measurements of ambient aerosols could be calculated as: $3 \times \sqrt{18} \times 0.016$ $\mathrm{Mm}^{-1}=0.2 \mathrm{Mm}^{-1}$. The upper and lower bounds of $\sigma_{\mathrm{abs}, \mathrm{BrC}}$ was calculated to be 28.8 and $27.1 \mathrm{Mm}^{-1}$ on average, respectively, which is within $3 \%$ difference compared to the mean value of $\sigma_{\mathrm{abs}, \mathrm{BrC}}\left(28.0 \mathrm{Mm}^{-1}\right)$.

Based on the improved AAE-based method, the temporal profiles of the estimated $\sigma_{\mathrm{abs}, \mathrm{BrC}}$ in Guangdong Atmospheric Supersite as well as the concentration of potassium, the correlation between $\sigma_{\mathrm{abs}, \mathrm{BrC}}$ and $\mathrm{BC}$ concentration, and the frequency histogram of the $\sigma_{\mathrm{abs}, \mathrm{BrC}} / \sigma_{\mathrm{abs}, 370 \mathrm{~nm}}$ are shown in Fig. 3. The estimated $\sigma_{\mathrm{abs}, \mathrm{BrC}} / \sigma_{\mathrm{abs}, 370 \mathrm{~nm}}$ distributed within a range of $30 \%-50 \%$, with an average value at $37.4 \% \pm 7.1 \%$. Significant correlation $\left(\mathrm{r}^{2}=0.72\right)$ between the estimated $\sigma_{\mathrm{abs}, \mathrm{BrC}}$ and BC demonstrates their similar sources (Andreae and Gelencser, 2006; Moosmüller et al., 2009; Saleh et al., 2013; Guo et al., 2014). The correlation between the estimated $\sigma_{a b s, B r C}$ and the concentration of potassium, which is commonly used as a marker for biomass burning activities, was also observed to be significant $\left(\mathrm{r}^{2}=0.38, p\right.$ $<0.001)$, indicative of potential contribution of biomass
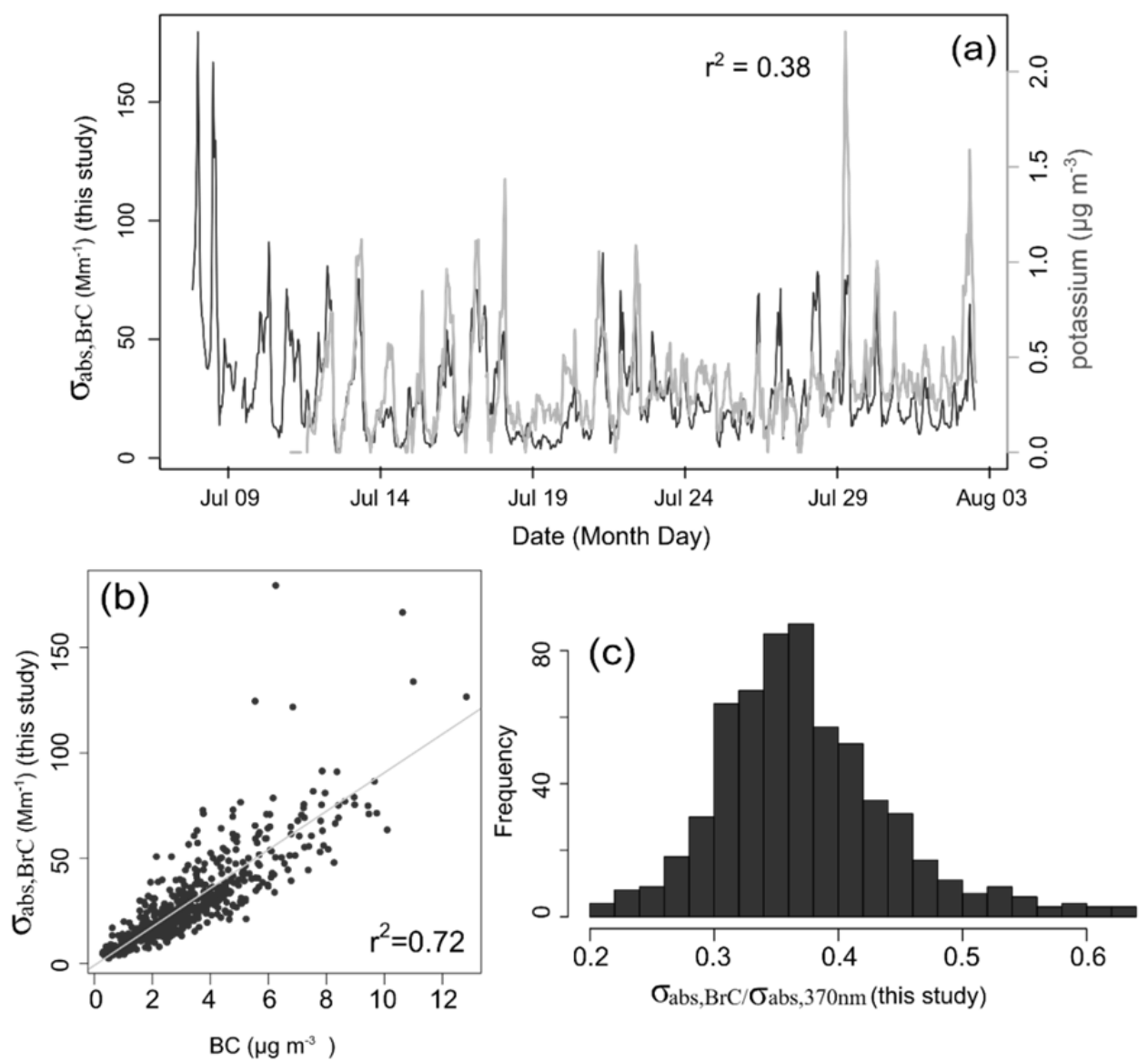

Fig. 3. (a) Temporal profile of $\sigma_{\mathrm{abs}, \mathrm{BrC}}$ and the concentration of potassium, (b) correlation analysis of $\sigma_{\mathrm{abs}, \mathrm{BrC}}$ and the concentration of $\mathrm{BC}$, and (c) the histogram summarizing of the $\sigma_{\mathrm{abs}, \mathrm{BrC}} / \sigma_{\mathrm{abs}, 370 \mathrm{~nm}}$ over this study. 
burning to the observed BrC (Lack et al., 2013; Saleh et al., 2014; Hsiao et al., 2016; Rathod et al., 2017) in the PRD region. Potassium originated from sea salt and dust (Pio et al., 2007) was estimated to be $<5 \%$ of the observed potassium in our study. Moderate correlation could be partly explained by that emission of $\mathrm{BrC}$ from biomass burning is linked to both burning condition and the emitted organic tracers (Lack et al., 2013; Saleh et al., 2014), and also other sources.

\section{Comparisons of the Method Developed in this Study with the Previous Methods}

Comparison with Method I

It is necessary to note that applying $\mathrm{AAE}=1$ to anchor absorption for $\mathrm{BC}$ and $\mathrm{BrC}$ may introduce potential errors, since the AAE for ambient particles (measured between a short and long visible wavelength) has often been observed to be variable, dependent on their physical and chemical properties (Mogo et al., 2012; Lack and Langridge, 2013). Fig. 1 shows the average AAE $(1.36 \pm 0.25$ and $0.70 \pm$ 0.07) of the ambient particles estimated from the linear fit (R1) of $\sigma_{a b s}$ over the wavelength of $370-520 \mathrm{~nm}$ and 880 $950 \mathrm{~nm}$, respectively.

Based on $\mathrm{AAE}=1$ assumption, $\sigma_{\mathrm{abs}, \mathrm{BrC}} / \sigma_{\mathrm{abs}, 370 \mathrm{~nm}}$ was calculated to be $16.8 \% \pm 11 \%$. While the estimated $\sigma_{\text {abs,BrC }} / \sigma_{\text {abs,370nm }}$ based on AAE $=\mathrm{AAE}_{880-950}$ (the developed method) and AAE $=1$ is highly correlated $\left(\mathrm{r}^{2}=0.78, p<\right.$ 0.001 , Fig. 4 ), the difference can be as large as $20 \%$ on average. There were some negative values obtained when assuming $\mathrm{AAE}=1$, because the observed $\mathrm{AAE}_{370-950}$ was lower than 1 during some periods. Therefore, an arbitrary attribution of AAE to be 1 may substantially underestimate the $\sigma_{\mathrm{abs}, \mathrm{BrC}} / \sigma_{\mathrm{abs}, 370 \mathrm{~nm}}$ in this study.

\section{Comparison with Method II}

Based on Method II, the average estimated $\sigma_{\mathrm{abs}, \mathrm{Br}} / \sigma_{\mathrm{abs}, 370 \mathrm{~nm}}$ over the study was $-2.4 \% \pm 11.5 \%$, which indicates that production of $\mathrm{BrC}$ dominated over evaporation, resulted in

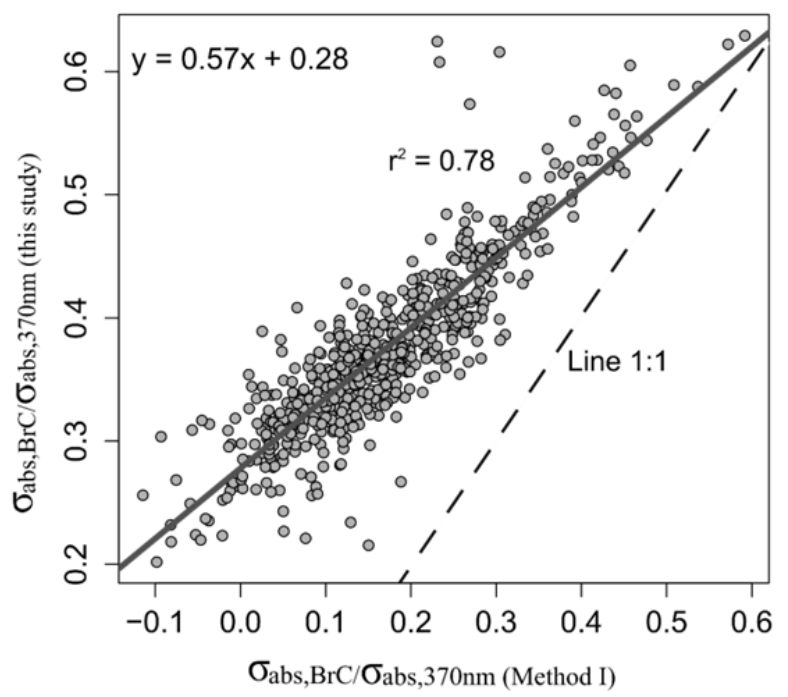

Fig. 4. Comparison of $\sigma_{\mathrm{abs}, \mathrm{BrC}} / \sigma_{\mathrm{abs}, 370 \mathrm{~nm}}$ estimated by our developed method and Methods I based on AAE $=1$. a net production of $\mathrm{BrC}$ when ambient aerosols were heated. Similar estimation in previous studies also resulted in the negative values for $\sigma_{\text {abs,BrC }} / \sigma_{\text {abs,370nm }}$ (Guo et al., 2014; McMeeking et al., 2014; Nakayama et al., 2014), and it was attributed to the production of $\mathrm{BrC}$ when ambient aerosols were heated (Nakayama et al., 2014). A comparison of the $\sigma_{\text {abs,BrC }} / \sigma_{\text {abs,370nm }}$ estimated by Method II and the developed method in Fig. 5 indicates that the production of BrC during heating periods can be substantially important, which may account for $>40 \%$ difference between the estimated $\sigma_{\mathrm{abs}, \mathrm{BrC}} / \sigma_{\mathrm{abs}, 370 \mathrm{~nm}}$, and thus should be emphasized when estimating $\sigma_{\mathrm{abs}, \mathrm{BrC}} / \sigma_{\mathrm{abs}, 370 \mathrm{~nm}}$ with Method II. The uncertain evaporation state of $\mathrm{BrC}$ during heating might be partly explained by the residue chemical information (Fig. S2). The increased difference during afternoon hours $(\sim 50 \%)$ (Fig. 5) may further indicate the influence of photochemical activity on the production of $\mathrm{BrC}$ during the heating periods. This could be evidenced by negative correlations $(p<0.001)$ between the estimated $\sigma_{\text {abs,BrC }} / \sigma_{\text {abs,370nm }}$ by Method II and the concentrations of secondary organic carbon (SOC, see SI) and $\mathrm{O}_{3}$ (Fig. 6). This connection is probably explained by the conversion of SOC to $\mathrm{BrC}$ when aerosols were heated, and the conversion should be improved when there are high levels of SOC and $\mathrm{O}_{3}$. Such fraction of $\mathrm{BrC}$ may be attributed to low volatility oxygenated organic
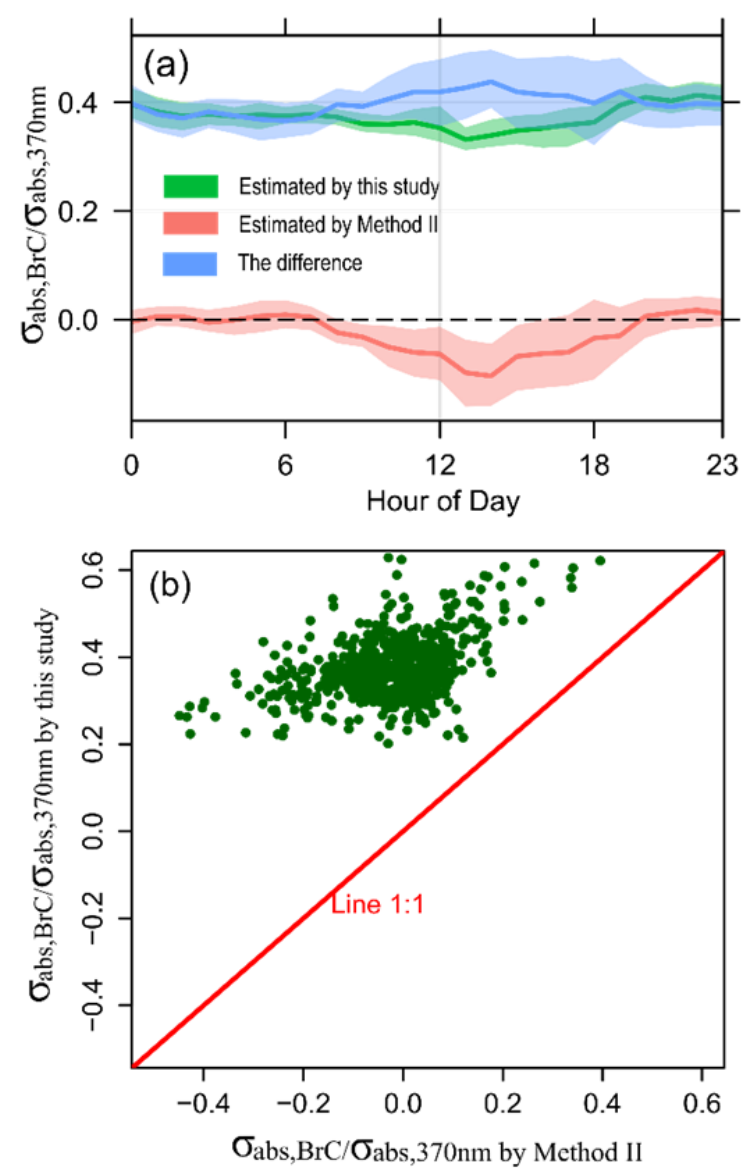

Fig. 5. Comparisons of (a) diurnal variations and (b) hourly averaged $\sigma_{\mathrm{abs}, \mathrm{BrC}} / \sigma_{\mathrm{abs}, 370 \mathrm{~nm}}$ estimated by Methods II and our developed method. 

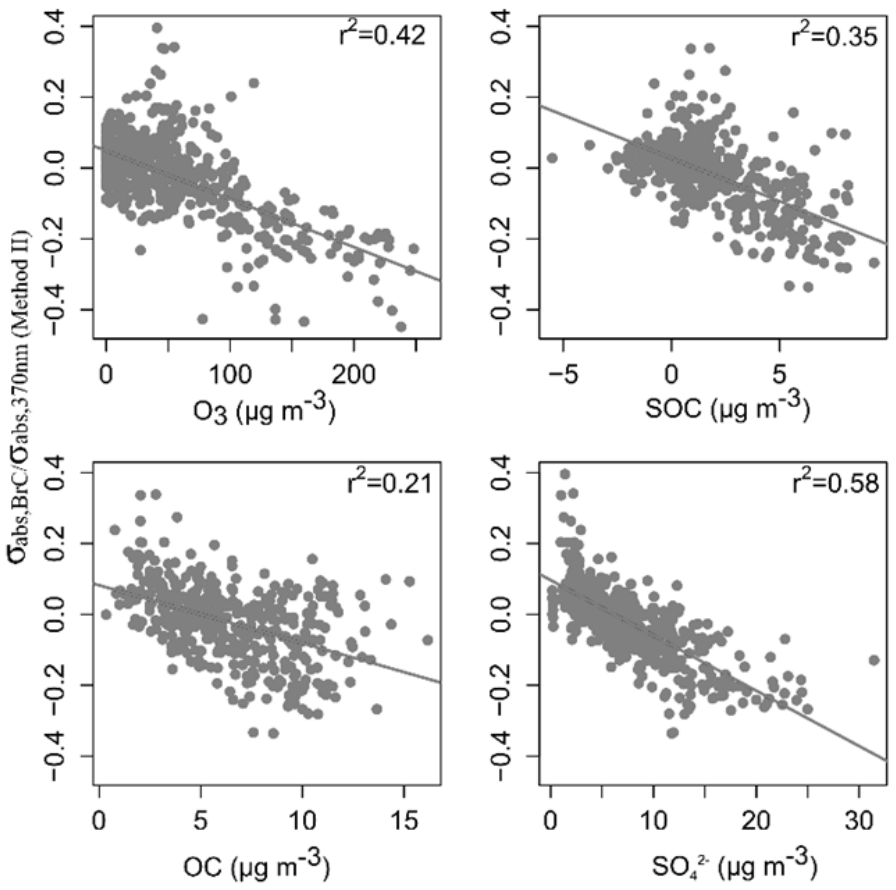

Fig. 6. Correlation plots between the $\sigma_{\mathrm{abs}, \mathrm{BrC}} / \sigma_{\mathrm{abs}, 370 \mathrm{~nm}}$ estimated by Method II and the concentrations of $\mathrm{O}_{3}$, SOC, OC and sulfate.

compounds, which has also been detected in heated $\left(300^{\circ} \mathrm{C}\right)$ particles (Poulain et al., 2014). Therefore, the estimated $\sigma_{\mathrm{abs}, \mathrm{BrC}} / \sigma_{\mathrm{abs}, 370 \mathrm{~nm}}$ based on Method II should suffer substantial error when there is high abundance of SOC.

From the co-located SPAMS, it was observed that detected number for internally mixed $\mathrm{OC}$ and sulfate (OCsulfate) particles, which is frequently observed in the atmosphere of PRD region (Zhang et al., 2015), substantially increased during noon hours when aerosols were heated (Fig. S3). More efficient detection of these particles in this case is probably linked to increased absorption of ablation laser by heated OC-sulfate particles (Hatch et al., 2014). Without strong absorbing EC cores, the increased absorption is therefore more likely attributed to the formation of absorptive species (i.e., $\mathrm{BrC}$ ) in heated $\mathrm{OC}$-sulfate particles. Together with significant correlation between the estimated $\sigma_{\mathrm{abs}, \mathrm{BrC}} / \sigma_{\mathrm{abs}, 370 \mathrm{~nm}}$ and $\mathrm{SOC}$ and sulfate (Fig. 6), it is suspected that the formed $\mathrm{BrC}$ during heating measurements might be linked to organosulfate, which was ionized to fragments representative of OC and sulfate in the internally mixed OC and sulfate particles (Hatch et al., 2011). Light absorption at shorter wavelength had been observed for organosulfate (Song et al., 2013). Although secondary organic aerosol (SOA) produced by photo-chemical ageing may contribute to $\mathrm{BrC}$ (Lambe et al., 2013; Saleh et al., 2013), our results indicate primary emission plays a dominant role. As discussed above, significant correlations between the estimated $\sigma_{\mathrm{abs}, \mathrm{BrC}}$ and $\mathrm{BC}$, and potassium were observed. Furthermore, there is no correlation $\left(\mathrm{r}^{2}<0.01\right)$ between the estimated $\sigma_{\text {abs,BrC }}$ and SOC (Fig. S4). As noted by Lambe et al. (2013), the extent of absorption by SOA is linked with the magnitude dependent on both precursor type and oxidation level.

\section{CONCLUSIONS}

This paper provides an improved AAE-based method of quantitatively estimating the light absorption by $\mathrm{BrC}$ in real-time based on multi-wavelength light absorption measurements. The analysis shows that the wavelength dependence of BC light absorption can be better approximated for higher (880-950 nm) wavelengths. Based on simultaneous measurements of $\sigma_{\text {abs }}$ for both ambient and heated aerosols, $\mathrm{AAE}_{880-950}$ was found to show a negligible response to the presence of $\mathrm{BrC}$; thus, the application of $\mathrm{AAE}=\mathrm{AAE}_{880-950}(0.70 \pm 0.07)$ for "pure" $\mathrm{BC}$, instead of $\mathrm{AAE}=1$, should be more accurate for estimating the light absorption by $\mathrm{BrC}$ in the $\mathrm{PRD}$ region. However, the estimated AAE value of approximately 0.7 in this work cannot represent all kinds of situations, in particular, when the $\mathrm{BrC}$ absorption over longer wavelengths is non-negligible. $\mathrm{BrC}$ was estimated to contribute $37.4 \%$ to the light absorption at $370 \mathrm{~nm}$ by the developed method, and it was largely attributed to primary emissions. The contribution is $>20 \%$ larger on average than that estimated by assuming the AAE to be equal to 1 . The results also suggest that the estimated contribution of $\mathrm{BrC}$ to the total light absorption at $370 \mathrm{~nm}$ based on the light absorption enhancement method might suffer from potential errors during high loadings of SOA, which might serve as evidence for the production of $\mathrm{BrC}$ when aerosols are heated - an aspect neglected in previous studies.

\section{ACKNOWLEDGEMENTS}

This work was supported by the National Nature Science Foundation of China (No. 41775124), the State Key 
Laboratory of Organic Geochemistry (SKLOGA201603A), and Guangdong Provincial Key Laboratory of Environmental Protection and Resources Utilization (2014B030301060). The authors would also like to thank all participants for the sampling at the Guangdong Atmospheric Supersite.

\section{SUPPLEMENTARY MATERIAL}

Supplementary data associated with this article can be found in the online version at http://www.aaqr.org.

\section{REFERENCES}

Ajtai, T., Filep, A., Utry, N., Schnaiter, M., Linke, C., Bozoki, Z., Szabo, G. and Leisner, T. (2011). Intercomparison of optical absorption coefficients of atmospheric aerosols determined by a multi-wavelength photoacoustic spectrometer and an Aethalometer under sub-urban wintry conditions. J. Aerosol Sci. 42: 859866.

Alexander, D.T.L., Crozier, P.A. and Anderson, J.R. (2008). Brown carbon spheres in East Asian outflow and their optical properties. Science 321: 833-836.

Andreae, M.O. and Gelencser, A. (2006). Black carbon or brown carbon? The nature of light-absorbing carbonaceous aerosols. Atmos. Chem. Phys. 6: 3131-3148.

Arnott, W.P., Hamasha, K., Moosmuller, H., Sheridan, P.J. and Ogren, J.A. (2005). Towards aerosol light-absorption measurements with a 7-wavelength Aethalometer: Evaluation with a photoacoustic instrument and 3wavelength nephelometer. Aerosol Sci. Technol. 39: 1729.

Bahadur, R., Praveen, P.S., Xu, Y.Y. and Ramanathan, V. (2012). Solar absorption by elemental and brown carbon determined from spectral observations. Proc. Natl. Acad. Sci. U.S.A. 109: 17366-17371.

Bergstrom, R.W., Pilewskie, P., Russell, P.B., Redemann, J., Bond, T.C., Quinn, P.K. and Sierau, B. (2007). Spectral absorption properties of atmospheric aerosols. Atmos. Chem. Phys. 7: 5937-5943.

Bi, X.H., Dai, S.H., Zhang, G.H., Qiu, N., Li, M., Wang, X.M., Chen, D.H., Peng, P.A., Sheng, G.Y., Fu, J.M. and Zhou, Z. (2015). Real-time and single-particle volatility of elemental carbon-containing particles in the urban area of Pearl River Delta region, China. Atmos. Environ. 118: 194-202.

Bond, T.C. and Bergstrom, R.W. (2006). Light absorption by carbonaceous particles: An investigative review. Aerosol Sci. Technol. 40: 27-67.

Cappa, C.D., Onasch, T.B., Massoli, P., Worsnop, D.R., Bates, T.S., Cross, E.S., Davidovits, P., Hakala, J., Hayden, K.L., Jobson, B.T., Kolesar, K.R., Lack, D.A., Lerner, B.M., Li, S.M., Mellon, D., Nuaaman, I., Olfert, J.S., Petaja, T., Quinn, P.K., Song, C., Subramanian, R., Williams, E.J. and Zaveri, R.A. (2012). Radiative absorption enhancements due to the mixing state of atmospheric black carbon. Science 337: 1078-1081.

Chen, X.J., Lai, S.C., Gao, Y., Zhang, Y.Y., Zhao, Y., Chen, D.H., Zheng, J.Y., Zhong, L.J., Lee, S.C. and
Chen, B. (2016). Reconstructed light extinction coefficients of fine particulate matter in rural Guangzhou, Southern China. Aerosol Air Qual. Res. 16: 1981-1990.

Cheng, Y., He, K.B., Zheng, M., Duan, F.K., Du, Z.Y., Ma, Y.L., Tan, J.H., Yang, F.M., Liu, J.M., Zhang, X.L., Weber, R.J., Bergin, M.H. and Russell, A.G. (2011). Mass absorption efficiency of elemental carbon and water-soluble organic carbon in Beijing, China. Atmos. Chem. Phys. 11: 11497-11510.

Cheng, Y.F., Wiedensohler, A., Eichler, H., Su, H., Gnauk, T., Brüggemann, E., Herrmann, H., Heintzenberg, J., Slanina, J., Tuch, T., Hu, M. and Zhang, Y.H. (2008). Aerosol optical properties and related chemical apportionment at Xinken in Pearl River Delta of China. Atmos. Environ. 42: 6351-6372.

Corr, C.A., Hall, S.R., Ullmann, K., Anderson, B.E., Beyersdorf, A.J., Thornhill, K.L., Cubison, M.J., Jimenez, J.L., Wisthaler, A. and Dibb, J.E. (2012). Spectral absorption of biomass burning aerosol determined from retrieved single scattering albedo during ARCTAS. Atmos. Chem. Phys. 12: 10505-10518.

Drinovec, L., Močnik, G., Zotter, P., Prévôt, A.S.H., Ruckstuhl, C., Coz, E., Rupakheti, M., Sciare, J., Müller, T., Wiedensohler, A. and Hansen, A.D.A. (2015). The "dual-spot" Aethalometer: An improved measurement of aerosol black carbon with real-time loading compensation. Atmos. Meas. Tech. 8: 1965-1979.

Favez, O., Alfaro, S.C., Sciare, J., Cachier, H. and Abdelwahab, M.M. (2009). Ambient measurements of light-absorption by agricultural waste burning organic aerosols. J. Aerosol Sci. 40: 613-620.

Feng, Y., Ramanathan, V. and Kotamarthi, V.R. (2013). Brown carbon: A significant atmospheric absorber of solar radiation? Atmos. Chem. Phys. 13: 8607-8621.

Guo, X.S., Nakayama, T., Yamada, H., Inomata, S., Tonokura, K. and Matsumi, Y. (2014). Measurement of the light absorbing properties of diesel exhaust particles using a three-wavelength photoacoustic spectrometer. Atmos. Environ. 94: 428-437.

Gyawali, M., Arnott, W.P., Lewis, K. and Moosmuller, H. (2009). In situ aerosol optics in Reno, NV, USA during and after the summer 2008 California wildfires and the influence of absorbing and non-absorbing organic coatings on spectral light absorption. Atmos. Chem. Phys. 9: 80078015.

Harrison, R.M., Beddows, D.C.S., Hu, L. and Yin, J. (2012). Comparison of methods for evaluation of wood smoke and estimation of UK ambient concentrations. Atmos. Chem. Phys. 12: 8271-8283.

Hatch, L.E., Creamean, J.M., Ault, A.P., Surratt, J.D., Chan, M.N., Seinfeld, J.H., Edgerton, E.S., Su, Y. and Prather, K.A. (2011). Measurements of isoprene-derived organosulfates in ambient aerosols by aerosol time-offlight mass spectrometry - Part 1: Single particle atmospheric observations in Atlanta. Environ. Sci. Technol. 45: 5105-5111.

Hatch, L.E., Pratt, K.A., Huffman, J.A., Jimenez, J.L. and Prather, K.A. (2014). Impacts of aerosol aging on laser desorption/ionization in single-particle mass spectrometers. 
Aerosol Sci. Technol. 48: 1050-1058.

Hsiao, T.C., Ye, W.C., Wang, S.H., Tsay, S.C., Chen, W.N., Lin, N.H., Lee, C.T., Hung, H.M., Chuang, M.T. and Chantara, S. (2016). Investigation of the CCN activity, $\mathrm{BC}$ and $\mathrm{UVBC}$ mass concentrations of biomass burning aerosols during the 2013 BASELInE Campaign. Aerosol Air Qual. Res. 16: 2742-2756.

Huang, X.F., Gao, R.S., Schwarz, J.P., He, L.Y., Fahey, D.W., Watts, L.A., McComiskey, A., Cooper, O.R., Sun, T.L., Zeng, L.W., Hu, M. and Zhang, Y.H. (2011). Black carbon measurements in the Pearl River Delta region of China. J. Geophys. Res. 116: 445-451.

Kirchstetter, T.W., Novakov, T. and Hobbs, P.V. (2004). Evidence that the spectral dependence of light absorption by aerosols is affected by organic carbon. J. Geophys. Res. 109: 21208.

Kirchstetter, T.W. and Thatcher, T.L. (2012). Contribution of organic carbon to wood smoke particulate matter absorption of solar radiation. Atmos. Chem. Phys. 12: 6067-6072.

Lack, D.A. and Cappa, C.D. (2010). Impact of brown and clear carbon on light absorption enhancement, single scatter albedo and absorption wavelength dependence of black carbon. Atmos. Chem. Phys. 10: 4207-4220.

Lack, D.A., Bahreni, R., Langridge, J.M., Gilman, J.B. and Middlebrook, A.M. (2013). Brown carbon absorption linked to organic mass tracers in biomass burning particles. Atmos. Chem. Phys. 13: 2415-2422.

Lack, D.A. and Langridge, J.M. (2013). On the attribution of black and brown carbon light absorption using the Angstrom exponent. Atmos. Chem. Phys. 13: 1053510543.

Lambe, A.T., Cappa, C.D., Massoli, P., Onasch, T.B., Forestieri, S.D., Martin, A.T., Cummings, M.J., Croasdale, D.R., Brune, W.H., Worsnop, D.R. and Davidovits, P. (2013). Relationship between oxidation level and optical properties of secondary organic aerosol. Environ. Sci. Technol. 47: 6349-6357.

Laskin, A., Laskin, J. and Nizkorodov, S.A. (2015). Chemistry of atmospheric brown carbon. Chem. Rev. 115: 4335-4382.

Li, L., Huang, Z. X., Dong, J. G., Li, M., Gao, W., Nian, H.Q., Fu, Z., Zhang, G.H., Bi, X.H., Cheng, P. and Zhou, Z. (2011). Real time bipolar time-of-flight mass spectrometer for analyzing single aerosol particles. Int. J. Mass. Spectrom. 303: 118-124.

Lin, C.C., Yang, L.S. and Cheng, Y.H. (2016). Ambient $\mathrm{PM}_{2.5}$, black carbon, and particle size-resolved number concentrations and the angstrom exponent value of aerosols during the firework display at the lantern festival in Southern Taiwan. Aerosol Air Qual. Res. 16: 373-387.

Liu, J., Scheuer, E., Dibb, J., Ziemba, L.D., Thornhill, K.L., Anderson, B.E., Wisthaler, A., Mikoviny, T., Devi, J.J., Bergin, M. and Weber, R.J. (2014). Brown carbon in the continental troposphere. Geophys. Res. Lett. 41: 2191-2195.

Liu, J., Scheuer, E., Dibb, J., Diskin, G.S., Ziemba, L.D., Thornhill, K.L., Anderson, B.E., Wisthaler, A., Mikoviny,
T., Devi, J.J., Bergin, M., Perring, A.E., Markovic, M.Z., Schwarz, J.P., Campuzano-Jost, P., Day, D.A., Jimenez, J.L. and Weber, R.J. (2015). Brown carbon aerosol in the North American continental troposphere: Sources, abundance, and radiative forcing. Atmos. Chem. Phys. 15: 7841-7858.

McMeeking, G.R., Fortner, E., Onasch, T.B., Taylor, J.W., Flynn, M., Coe, H. and Kreidenweis, S.M. (2014). Impacts of nonrefractory material on light absorption by aerosols emitted from biomass burning. J. Geophys. Res. 119: 12272-12286.

Mogo, S., Cachorro, V. E., de Frutos, A. and Rodrigues, A. (2012). Absorption Angstrom exponents of aerosols and light absorbing carbon (LAC) obtained from in situ data in Covilha, central Portugal. J. Environ. Monit. 14: 3174-3181.

Moosmüller, H., Chakrabarty, R.K. and Arnott, W.P. (2009). Aerosol light absorption and its measurement: A review. J. Quant. Spectrosc. Radiat. Transfer 110: 844878.

Moosmüller, H., Chakrabarty, R.K., Ehlers, K.M. and Arnott, W.P. (2011). Absorption Ångström coefficient, brown carbon, and aerosols: Basic concepts, bulk matter, and spherical particles. Atmos. Chem. Phys. 11: 12171225.

Nakayama, T., Ikeda, Y., Sawada, Y., Setoguchi, Y., Ogawa, S., Kawana, K., Mochida, M., Ikemori, F., Matsumoto, K. and Matsumi, Y. (2014). Properties of light-absorbing aerosols in the Nagoya urban area, Japan, in August 2011 and January 2012: Contributions of brown carbon and lensing effect. J. Geophys. Res. 119: 12721-12739.

Pintér, M., Ajtai, T., Kiss-Albert, G., Kiss, D., Utry, N., Janovszky, P., Palásti, D., Smausz, T., Kohut, A., Hopp, B., Galbács, G., Kukovecz, Á., Kónya, Z., Szabó, G. and Bozóki, Z. (2018). Thermo-optical properties of residential coals and combustion aerosols. Atmos. Environ. 178: 118-128.

Poulain, L., Birmili, W., Canonaco, F., Crippa, M., Wu, Z.J., Nordmann, S., Spindler, G., Prevot, A.S.H., Wiedensohler, A. and Herrmann, H. (2014). Chemical mass balance of 300 degrees $\mathrm{C}$ non-volatile particles at the tropospheric research site Melpitz, Germany. Atmos. Chem. Phys. 14: 10145-10162.

Qin, Y.M., Tan, H.B., Li, Y.J., Schurman, M.I., Li, F., Canonaco, F., Prevot, A.S.H. and Chan, C.K. (2017). Impacts of traffic emissions on atmospheric particulate nitrate and organics at a downwind site on the periphery of Guangzhou, China. Atmos. Chem. Phys. 17: 1024510258

Rathod, T., Sahu, S.K., Tiwari, M., Yousaf, A., Bhangare, R.C. and Pandit, G.G. (2017). Light absorbing properties of brown carbon generated from pyrolytic combustion of household biofuels. Aerosol Air Qual. Res. 17: 108116.

Rumsey, I.C., Cowen, K.A., Walker, J.T., Kelly, T.J., Hanft, E.A., Mishoe, K., Rogers, C., Proost, R., Beachley, G.M., Lear, G., Frelink, T. and Otjes, R.P. (2014). An assessment of the performance of the Monitor for 
AeRosols and GAses in ambient air (MARGA): A semicontinuous method for soluble compounds. Atmos. Chem. Phys. 14: 5639-5658.

Saleh, R., Hennigan, C.J., McMeeking, G.R., Chuang, W.K., Robinson, E.S., Coe, H., Donahue, N.M. and Robinson, A.L. (2013). Absorptivity of brown carbon in fresh and photo-chemically aged biomass-burning emissions. Atmos. Chem. Phys. 13: 7683-7693.

Saleh, R., Robinson, E.S., Tkacik, D.S., Ahern, A.T., Liu, S., Aiken, A.C., Sullivan, R.C., Presto, A.A., Dubey, M.K., Yokelson, R.J., Donahue, N.M. and Robinson, A.L. (2014). Brownness of organics in aerosols from biomass burning linked to their black carbon content. Nature Geosci. 7: 647-650.

Sandradewi, J., Prevot, A.S.H., Weingartner, E., Schmidhauser, R., Gysel, M. and Baltensperger, U. (2008). A study of wood burning and traffic aerosols in an Alpine valley using a multi-wavelength Aethalometer. Atmos. Environ. 42: 101-112.

Shamjad, P.M., Tripathi, S.N., Pathak, R., Hallquist, M., Arola, A. and Bergin, M.H. (2015). Contribution of brown carbon to direct radiative forcing over the IndoGangetic Plain. Environ. Sci. Technol. 49: 10474-10481.

Shrestha, R., Kim, S.W., Yoon, S.C. and Kim, J.H. (2014). Attribution of aerosol light absorption to black carbon and volatile aerosols. Environ. Monit. Assess. 186: 47434751.

Song, C., Gyawali, M., Zaveri, R.A., Shilling, J.E. and Arnott, W.P. (2013). Light absorption by secondary organic aerosol from alpha-pinene: Effects of oxidants, seed aerosol acidity, and relative humidity. J. Geophys. Res. 118: 11741-11749.

Stevanovic, S., Miljevic, B., Madl, P., Clifford, S. and Ristovski, Z. (2015). Characterisation of a commercially available thermodenuder and diffusion drier for ultrafine particles losses. Aerosol Air Qual. Res. 15: 357-363.

Utry, N., Ajtai, T., Filep, Á., Pintér, M., Török, Z., Bozóki, Z. and Szabó, G. (2014). Correlations between absorption Angström exponent (AAE) of wintertime ambient urban aerosol and its physical and chemical properties. Atmos. Environ. 91: 52-59.

Villani, P., Picard, D., Marchand, N. and Laj, P. (2007). Design and validation of a 6-volatility tandem differential mobility analyzer (VTDMA). Aerosol Sci. Technol. 41: 898-906.
Wu, Y.F., Yan, P., Tian, P., Tao, J., Li, L., Chen, J.M., Zhang, Y.M., Cao, N.W., Chen, C. and Zhang, R.J. (2015). Spectral light absorption of ambient aerosols in urban Beijing during summer: An intercomparison of measurements from a range of instruments. Aerosol Air Qual. Res. 15: 1178-1187.

Yang, M., Howell, S.G., Zhuang, J. and Huebert, B.J. (2009). Attribution of aerosol light absorption to black carbon, brown carbon, and dust in China - Interpretations of atmospheric measurements during EAST-AIRE. Atmos. Chem. Phys. 9: 2035-2050.

Yuan, J.F., Huang, X.F., Cao, L.M., Cui, J., Zhu, Q., Huang, C.N., Lan, Z.J. and He, L.Y. (2016). Light absorption of brown carbon aerosol in the PRD region of China. Atmos. Chem. Phys. 16: 1433-1443.

Zhang, G.H., Bi, X.H., Chan, L.Y., Wang, X.M., Sheng, G.Y. and Fu, J.M. (2013a). Size-segregated chemical characteristics of aerosol during haze in an urban area of the Pearl River Delta region, China. Urban Clim. 4: 7484.

Zhang, X., Lin, Y.H., Surratt, J.D. and Weber, R.J. (2013b). Sources, composition and absorption Ångström exponent of light-absorbing organic components in aerosol extracts from the Los Angeles Basin. Environ. Sci. Technol. 47: 3685-3693.

Zhang, G.H., Bi, X.H., He, J.J., Chen, D.H., Chan, L.Y., Xie, G.W., Wang, X.M., Sheng, G.Y., Fu, J.M. and Zhou, Z. (2014). Variation of secondary coatings associated with elemental carbon by single particle analysis. Atmos. Environ. 92: 162-170.

Zhang, G.H., Han, B.X., Bi, X.H., Dai, S.H., Huang, W., Chen, D.H., Wang, X.M., Sheng, G.Y., Fu, J.M. and Zhou, Z. (2015). Characteristics of individual particles in the atmosphere of Guangzhou by single particle mass spectrometry. Atmos. Res. 153: 286-295.

Zhu, J., Crozier, P.A. and Anderson, J.R. (2013). Characterization of light-absorbing carbon particles at three altitudes in East Asian outflow by transmission electron microscopy. Atmos. Chem. Phys. 13: 6359-6371.

Received for review, December 28, 2017 Revised, May 31, 2018 Accepted, June 7, 2018 